\title{
Task-Based Language Teaching: An Approach in the Spotlight to Propel Language Learning Forward
}

\author{
Yunus Yildiz ${ }^{1}$ \\ ${ }^{1}$ Department of English Language Teaching, Faculty of Education, Tishk International University, Erbil, \\ Iraq \\ Correspondence: Yunus Yildiz, Tishk International University, Erbil, Iraq \\ Email: yunus.yildiz@tiu.edu.iq
}

doi: 10.23918/ijsses.v7i1p72

\begin{abstract}
Although some concerns have been raised about its efficiency in teaching language forms, TaskBased Language Teaching has been effectively applied in the language classroom to propel language learning forward. The implementation of tasks is conducive to communication and language learning. Tasks are potential building blocks in language development to support the learning process. As emphasis on meaning comes to the fore in this approach, immersing learners in tasks provides them opportunities to negotiate meaning and communicate effectively. This article aims to point out the characteristics of the approach and its effectiveness on the development of communication
\end{abstract}

Keywords: Task, Task-Based Language Learning, Communication, Language Acquisition, Meaning

\section{Introduction}

Owing to its pivotal role on the development of communicative approach, Task-Based Language Teaching (TBLT) has been receiving attention since the early 1980s. One of the main reasons for this attention is its primary focus on meaning rather than form. As emphasis on meaning comes to the fore in TBLT, this approach is linked with authenticity (Skehan, 1996). Language learning takes place in a natural learning environment and more progress in promoting language acquisition can be observed when learners are engaged with meaningful activities with authentic materials (Yildiz, 2016). The use of TBLT has been embraced by many researchers (Ellis, 2003; Skehan, 2003; Nunan, 2004; Van den Branden, Bygate \& Norris, 2009; Yildiz, 2015). Richards and Rodgers (2004) argue that "engaging learners in task work provides a better context for the activation of learning processes (p. 223).

Several definitions of task exist; for instance, Prabhu (1987) who first established TBLT defines a task as an activity in which learners arrive at an outcome from given information through some teacher-regulated process of thought. According to Nunan (1989) a task is "a piece of classroom work which involves learners in comprehending, manipulating, producing or interacting in the target language while their attention is primarily focused on meaning rather than form" (p. 10). Willis (1996) stresses the influence of task on communication performance and defines it as an activity "where the target language is used by the learner for a communicative purpose in order to achieve an outcome" (p. 23). Samuda and Bygate (2008) define a task as 'a holistic activity which engages language use in order to achieve some nonlinguistic outcome while meeting a linguistic challenge, with the overall aim of promoting language 
learning, through process or product or both' (p. 69). And Van den Branden (2006) defines task as "an activity in which a person engages in order to attain an objective, and which necessitates the use of language" (p. 4). All definitions share the idea that task is a meaning-focused and a goal-oriented activity designed to enable learners reach a desired outcome in language development. Bygate, Skehan, and Swain (2001) advocating this idea offer a core definition and see task as "an activity requires learners to use the target language with an emphasis on meaning, to attain an objective" (p. 11). With the help of conducting activities in the target language, language learners are engaged in meaningful communication and convey messages, and find an opportunity to enhance their communicative skills.

\section{Features of a Task}

In addition to the above-mentioned definitions of task, Ellis (2003) has added his own concise definition and pointed out that "tasks are activities that call for primarily meaning-focused language use" (p. 3). Furthermore, Ellis (2003, pp. 9-10) has identified the critical features of a task:

1) A task is a workplan

2) A task involves primary focus on meaning

3) A task involves real-world processes of language use

4) A task can involve any of the four language skills

5) A task engages cognitive processes

6) A task has a clearly defined communicative outcome

Similarly, Shekan (1998, p. 147) puts forward five characteristics of a task as:

1) Meaning is of paramount importance

2) Learners are not given other people's meaning to regurgitate

3) Task has a relationship with real world activities

4) Task completion has significance

5) The assessment of the task is in terms of outcome

A task engages learners to reach an objective by means of using the target language. Even the cultural elements and objects in teaching a foreign language will provide high adaptation and motivation (Celik \& Yildiz, 2019). Van den Branden (2006) argues that the objective of learners is to promote communication. Communication takes place in a learning environment in which learners have an opportunity to exchange meaningful thoughts. To put it more clearly, the implementation of tasks is conducive to communication and language learning. TBLT views language as a tool to develop communication because as Van den Branden (2006) suggests the use of tasks encourages learners to act as language user, and not a language learner. Wells (2000) stresses the use of language in a natural setting and argues that "the natural use of the target language for all communication is a sure sign of a good modern language course" (p. 110). Within this context, the use of tasks in language learning has a positive impact on learners' production.

In order language acquisition to occur, interaction holds a very important place. Fotos (2002) points out that a "task can supply the learner with target language input that is rich in communicative usages of problematic target structures, and task performance provides opportunities for the type of learner interaction suggested to promote language acquisition; that is opportunities to produce the target language 
and receive feedback on the productions" (p.138). When learners receive feedback Fotos argues, learners stand a better chance of noticing the gap between their current and desired proficiency levels.

\section{Characteristics of Task-Based Teaching}

Scrivener (2011) defines task-based learning (TBL) as 'a variant of CLT [communicative language teaching] ... which bases work cycles around the preparation for, doing of, and reflection and analysis of tasks that reflect real-life needs and skills' (p. 32). Feez (1998, p. 17) outlines the key elements of TBLT as:

1) The focus is on process rather than product

2) Basic elements are purposeful activities and tasks that emphasize communication and meaning

3) Learners learn language by interacting communicatively and purposefully while engaged in the activities and tasks

4) Activities and tasks can be either those that learners might need to achieve in real life or those that have a pedagogical purpose specific to the classroom

5) Activities and tasks of a task-based syllabus are sequenced according to difficulty

6) The difficulty of a task depends on range of factors including the previous experience of the learner, the complexity of the task, the language required to undertake the task, and the degree of support available.

Engaging learners in activities that involve real communication is the core of language learning (Mart, 2012; Mart, 2017; Mart, 2018a; Mart, 2019a). Also, activities which enable learners to use the target language to conduct meaningful tasks imply learning and lead to meaningful communication (Mart, 2018b). Tasks are potential building blocks in language development to support the learning process. Immersing learners in tasks provide them opportunities to negotiate meaning and communicate effectively. Being involved in a task work enable learners to focus their attention to comprehension, manipulation and production (Nunan, 1989). The interaction of learners in the target language propels their learning forward (Mart, 2020). Van den Branden (2006) argues that TBLT is student-centered; for that reason, learners are active recipients of language knowledge and they take a central role in their own learning.

Nunan (1991, p. 279) lists the five characteristics of TBLT as:

1) An emphasis on learning to communicate through interaction in the target language

2) The introduction of authentic texts into the learning situation

3) The provision of opportunities for learners to focus not only language, but also on the learning process itself

4) An enhancement of the learner's own personal experiences as important contributing elements to classroom learning

5) An attempt to link classroom language learning with language activation outside the classroom

Despite its increasing interest in language learning, TBLT has received some criticism in terms of its potency in teaching language forms. Sato (2010) raised a concern about the efficiency of the approach on the use of forms and argues that "the effectiveness of TBLT, especially in teaching grammar can be questioned" (p. 191). However, learners focus on task completion and give priority to do the tasks better. 
This fact not only allows them to develop their strategic problem solving skills, but also involve in lexicalized communication (Skehan, 2009).

Bringing together form and meaning is of primary importance in language teaching (Van Patten, 1990; Mart 2019b). Though it is difficult to acquire them simultaneously (Skehan, 1996), fluency and accuracy need to be effectively balanced to achieve the desired goals. The choice of task-based activities is of primary importance to enable learners pay balanced attention to fluency and accuracy. While easy tasks do not present any challenges in terms of fluency and accuracy, difficult ones emphasize fluency and cause learners to regard accuracy as less important (Skehan, 1996). In Task-based learning models presented by Ellis (2003) and Willis (1996) there is some attention to form although it is not the predominant focus of the approach. Ellis (2003) presented a model which has three stages: pre-task, during task and post-task, the model and Willis (1996) also suggested a model with three stages: pre-task, task cycle and language focus.

Both form and meaning are important components in language learning. For an efficient learning to take place both should be emphasized in the activities. Although form is moved to a secondary place in TBLT, learners can gain linguistic skills while performing the task. The activities learners practice will provide them opportunities to learn language features. Krahnke (1987) argues that TBLT has the potential to foster "communicative competence, including linguistic, sociolinguistic, discourse and strategic competence" (p. 59). Learners develop their linguistic and sociolinguistic competence when they are processing the information they use while performing the task. Krahnke (1987) goes on to explain that "strategic competence, or the ability to use communicative strategies, is acquired through the need for understanding during the interaction required to accomplish the tasks" (p. 59). That students give their opinions and exchange ideas while practicing the tasks enable them to reach the desired outcome in language learning.

TBLT is useful in that it offers an advantage to learners to interact spontaneously. Learners try out the grammar and vocabulary they know; moreover, they while listening to others they stand a better chance of noticing the language they used and have an opportunity to develop their communicative competence. By doing so, learners build their self confidence and gain more ambition. The use of language in communication situations leads to automaticity; for that reason, TBLT has the potential to develop learners' automaticity. Another advantage of TBLT is its role in the enhancement of vocabulary knowledge. Learners need to practice the language to meet the task goals. The use of language purposefully encourages them to reinforce their vocabulary learning.

\section{Conclusion}

TBLT places emphasis on learning to communicate by means of interaction using the target language; therefore, it is viewed as meaning-focused work. The focus on language is left aside. The core tenet of TBLT is that language learning takes place in a natural learning environment and more progress in promoting language acquisition can be observed when learners are exposed to meaningful activities by means of authentic materials. In TBLT through conducting activities in the target language, language learners are engaged in meaningful communication and find an opportunity to enhance their communicative skills. 


\section{References}

Bygate, M., Skehan, P., \& Swain, M. (Eds.). (2001). Researching pedagogic tasks: Second language learning, teaching and testing. London, UK: Longman.

Celik, B., \& Yildiz, Y. (2019). The role of foreign language culture on teaching the language and learner motivation. International Journal of Social Sciences \& Educational Studies, 5(4), 150.

Ellis, R. (2003). Task-based language learning and teaching. Oxford: Oxford University Press.

Feez, S. (1998). Text-based syllabus design. Sydney: National Centre for English Teaching and Research.

Fotos, S. (2002). Struture-based interactive tasks for the EFL grammar learner. In Hinkel, E., and Fotos, S. (Eds.). Perspectives on grammar teaching in second language classrooms. New Jersey: Lawrence Erlbaum Associates Publishers.

Krahnke, K. (1987). Approaches to syllabus design for foreign language teaching. Washington, D.C., Center for Applied Linguistics/Eaglewood Cliffs, NJ: Prentice Hall.

Mart, Ç, T. (2012). Developing Speaking Skills through Reading. International Journal of English Linguistics, 2(6), 91-96.

Mart, Ç.T. (2017). Literary texts: A means to promote language proficiency of upper-intermediate level EFL students. Journal of Education in Black sea Region, 2(2), 44-55.

Mart, Ç.T. (2018a). Literature in the language classroom: A recipe to maximize learning. L1 Educational Studies in Language and Literature, 18, 1-25.

Mart, Ç.T. (2018b). From communicative competence to language development. International Journal of English Linguistics, 8(2), 163-167.

Mart, Ç.T. (2019a). Reflections on discussions of literature: A language learning environment to promote speaking skills. The Journal of Social Sciences Research, 5(4), 846-850.

Mart, Ç, T. (2019b). A comparison of form-focused, content-based and mixed approaches to literaturebased instruction to develop learners' speaking skills. Cogent Education, 6(1), 1-27.

Mart, Ç, T. (2020). Integrating Listening and Speaking Skills to Promote Speech Production and Language Development. MEXTESOL Journal, 44(2), 1-7.

Nunan, D. (1989). Designing tasks for the communicative classroom. Cambridge: Cambridge University Press.

Nunan, D. (1991). Communicative tasks and the language curriculum. TESOL Quarterly, 25(1), 279295.

Nunan, D. (2004). Task-based language teaching. Cambridge: Cambridge University Press.

Prabhu, N. S. (1987). Second language pedagogy. Oxford: Oxford University Press.

Richards, J., \& Rodgers, T. (2004). Approaches and methods in language teaching. Cambridge: Cambridge University Press.

Samuda, V., \& Bygate, M. (2008). Tasks in second language learning. New York: Palgrave Macmillan.

Scrivener, J. (2011). Learning teaching. 3rd edition. Oxford: Macmillan.

Skehan, P. (1996). A framework for the implementation of Task-based instruction. Applied Linguistics, 17(1), 38-62.

Skehan, P. (2003). Task-based instruction. Language Education, 36, 1-14.

Skehan, P. (1998). A cognitive approach to language learning. Oxford: Oxford University Press.

Skehan, P. (2009). A framework for the implementation of task-based instruction. In Van den Branden, K., Bygate, M., Norris, J (Eds.). Task-based language teaching. Amsterdam: John Benjamin B.V.

Van den Branden, K. (2006). Task based language education. From theory to practice. Cambridge: Cambridge University Press.

Van den Branden, K., Bygate, M., \& Norris, J. (2009). Task-based language teaching: Issues, research and practice. Amsterdam: Benjamins. 
Van Patten, B. (1990). Attending to content and form m the input: An experiment in consciousness'. Studies in Second Language Acquisition, 12, 287-301.

Wells, G. J. (2000). Reflections on grammar implicit language teaching. London: Center for Information on Language Teaching and Research.

Willis, J. (1996). A framework for task-based learning. Harlow: Longman

Yildiz, Y. (2015). The key to success in English learning can be involvement in extracurricular. International Journal of Thesis Projects and Dissertations (IJTPD), 3, 24-28.

Yildiz, Y. (2016). The role of extracurricular activities in the academic achievement of English as foreign language (EFL) students In Iraqi universities (A case of Ishik University preparatory school). PhD Dissertation. Tbilisi: International Black Sea University. 